Pringsheim, E. G. (1955). J. gen. Microbiol. 13, 285-291

\title{
Lampropedia hyalina Schroeter 1886 and Vannielia aggregata n.g., n.sp., with Remarks on Natural and on Organized Colonies in Bacteria
}

\author{
By E. G. PRINGSHEIM* \\ Strangeways Research Laboratory, Cambridge
}

SUMMARY: Two bacteria, Lampropedia hyalina and Vannielia aggregata, are described, which form characteristically shaped aggregations. The differences between artificial, natural and organized colonies are discussed.

Lampropedia hyalina was observed in April 1951 in liquid manure of brown colour from a dairy farmyard on Madingley Road, Cambridge. After 1 day's standing in the laboratory loops-full from the surface contained the following organisms: great numbers of Spirillum spp. of various sizes in part distorted; Polytoma uvella; small colourless flagellates; bacteria in chains, often with longitudinal division so that two parallel rows originated; a large bacterial rod in chains (Lineola?); motile sarcinas, cells $2-3 \mu$. in diameter, arranged in cubiform clusters, the smaller ones being more active; and bacterial aggregates with growth in one plane though not always flat, some of them swimming in a sort of unbalanced swaying movement.

It is this last organism which was taken into culture and is believed to be identical with Schroeter's (1886) Lampropedia hyalina, in spite of its initial motility which was lost on culturing. If there was not perhaps a confusion with the Sarcina (which is not very likely, but cannot be checked any more) Lampropedia would be in synonymy with Pedioplana haeckeli Wolff (1907) which recalls a flagellate Lampropedia ('erinnert an eine mit Geisseln versehene Lampropedia'). This had been found in rotting-portions of mangel-wurzels or swedes, and such were also present in the dung-heap from which the manure for this investigation was taken. Lampropedia was first observed in muddy water and probably given its name because under the microscope it appeared like glistening tablets. Lampropedia is one of the relatively few bacteria which can be recognized under the microscope. It does not seem to be rare and may occur in enormous numbers. Gonium hyalinum Ehrenberg (1838), Merismopedia hyalina Kützing (1845-71) and Micrococcus hyalinus Migula (1897-1900) were probably identical with Lampropedia. The species may be planktonic, but is more often found as a film covering dirty mud or the overlying water. Kolkwitz (1909, p. 90) records it from several of the lakes near Berlin which are polluted by waters from neighbouring habitations, and considers it to be a mud organism.

Plating of the original material failed to produce colonies of Lampropedia, owing to the overwhelming number of other bacteria, but single tablets

* Present address : Pflanzenphysiologisches Institut der Universität Göttingen, Germany. 
transferred with a capillary pipette to soil-water cultures with starch or a wheat grain on the bottom gave rise to mixed cultures. Lampropedia tablets appeared after a few days in great numbers in the surface film and could be transferred again with a capillary to agar plates where they were streaked out with a loop. After one day at room temperature a few isolated colonies were

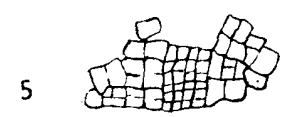

a

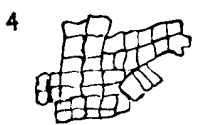

a

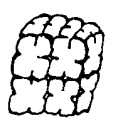

3

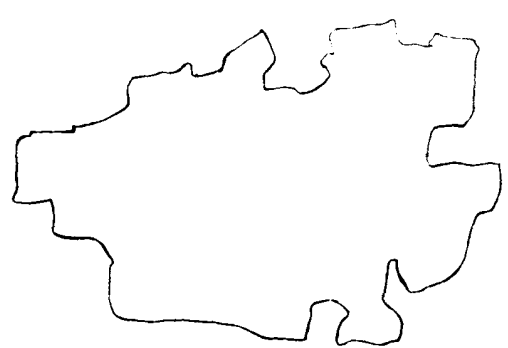

b

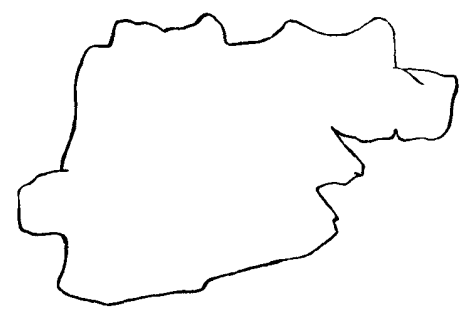

b
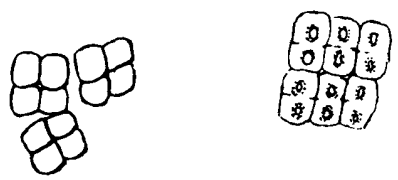

2

1

Figs. 1-5. Lampropedia hyalina.

Fig. 1. Group of three tetrads. $\times 3000$. Fig. 2 . Small plate, vitally stained with neutral red. $\times 3000$. Fig. 3. Colony of a sarcina associated with Lampropedia at the original habitat. $\times 3000$. Figs. $4 a, b$ and $5 a, b$. Two examples of: $a$, small initial group, a fragment of a previous growth, transferred to a new agar plate; and $b$, the same in outlines after 1 day at room temperature. $\times 1500$.

observed on agar with $0 \cdot 1 \%$ sodium acetate, $\mathbf{0} \cdot \mathbf{2} \%$ Difco yeast extract and $\mathbf{0} \cdot \mathbf{1} \%$ Difco tryptone. It was found later that acetate was not necessary to obtain growth of this bacterium, but served only to neutralize the otherwise slightly acid medium. Lampropedia multiplies only in neutral or weak alkaline media. By repeating the plating procedure, pure cultures were 
obtained. They multiplied still better at higher concentrations of nutrient substances, for instance $0.5 \%$ Difco Bacto peptone or Difco tryptone $+0.5 \%$ Difco yeast extract, $\mathrm{pH}$ 7, or similar mixtures as used for other bacteria. The most luxuriant growth was observed on the medium devised for Caryophanon

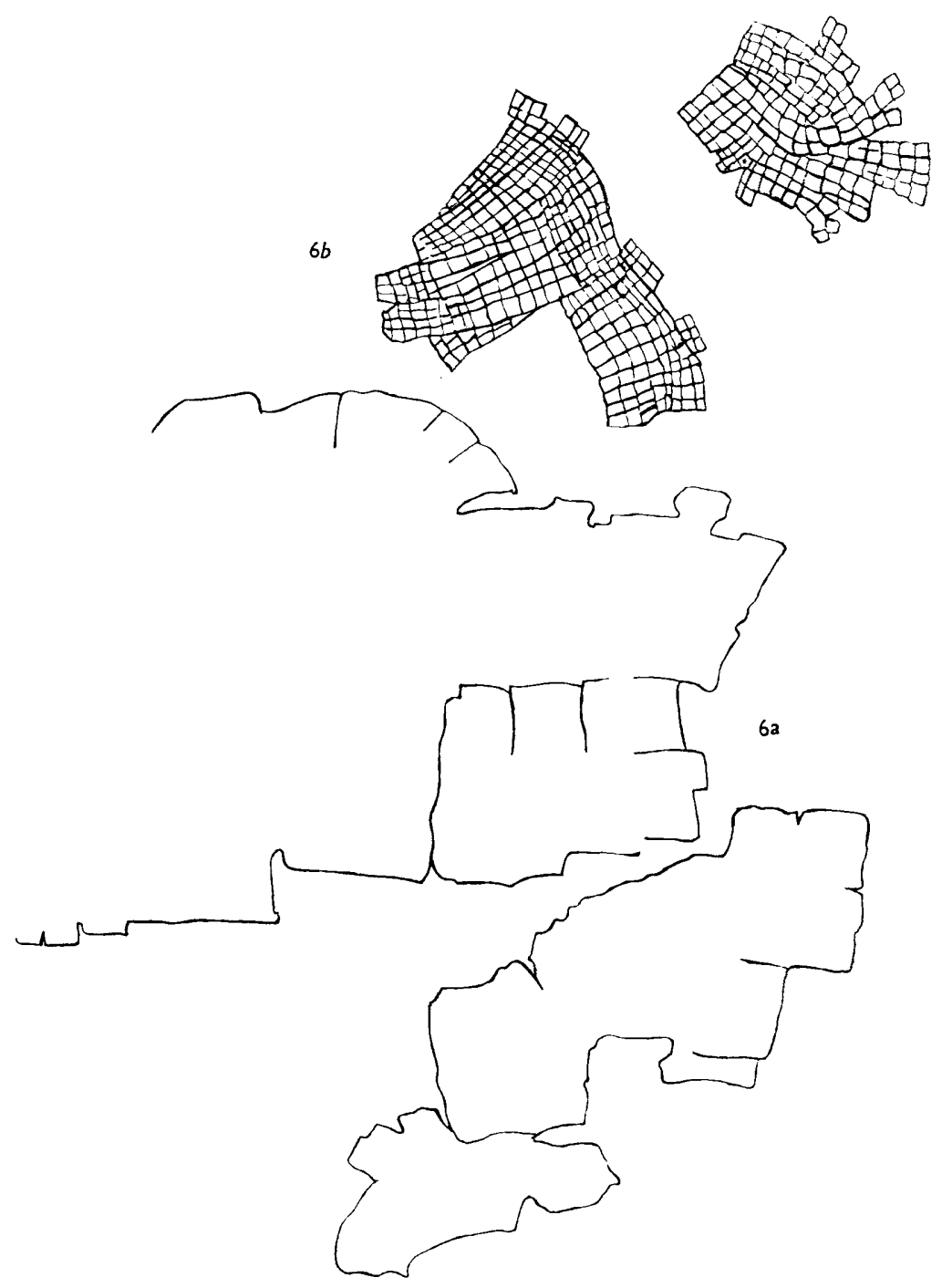

Fig 6. Lampropedia hyalina. a, outlines of part of a 3-day old growth on agar plate; $b$, details with cell margins shown.

latum (Pringsheim \& Robinow, 1947) and composed as follows: sodium acetate $0.1 \%$, beef extract $0 \cdot 1 \%$, yeast extract $0.2 \%$, agar $1.5 \%$.

The growth on agar slopes may be very luxurious when the medium has been neutralized and is damp enough. The development of the small squarish fragments transferred to the wet agar surface with a loop can best be followed 
on Pl. 1 and in Figs. 4 and 5. The ensuing sheets extend while growing in all directions, their margins slipping over the agar. Only when there is more friction, either because the watery surface film has evaporated or because the sheets meet, do they get wrinkled and folded or roll up at the borders ( $\mathrm{Pl}$. 1, fig. 5). There is never a diffuse growth of single or paired cells. In liquid media, the growth adheres to the glass wall and eventually falls to the bottom or reaches the surface. Only in the latter case does a thriving development occur. The cell aggregates are then not readily wetted, and their upper surface appears to grow less than the lower, or there is some shrinking so that the cell plates curve and attain irregular shapes (Pl. 1, fig. 6).

Vannielia aggregata n.g., n.sp. was found with Spirogyra in June 1953 in a jar of putrifying mud from Coe Fen, a piece of pasture land in Cambridge with ditches and trees. Ecologically the habitat is characterized by a tendency towards polytrophic conditions as borne out by the occurrence of various Euglenaceae, mainly Euglena viridis, Phacus pyrum and Eutreptia viridis, of Spirillum, Chlamydomonas, and Eudorina spp., Spirulina albida and Sphaerotilus natans.

Pink patches appeared on the edge of the fluid away from the light, composed of motile organisms which re-assembled after mechanical disturbance. They turned out to be clusters of radiately arranged bacterial rods. These clusters were ovoid to spherical in shape and 15-17 $\mu$. in diameter, rotating with the help of flagella, one to each cell, and markedly phototactic. The roundish clusters were not very regular, pinkish in the centre, but not appreciably coloured in the peripheral half of the radius. The individual rods were about $1 \mu$. across, 4-6 $\mu$. long, and Gram-negative. After drying, methylene blue and particularly fuchsin stained them well. Indian ink and nigrosin failed to demonstrate a mucilaginous area around the colonies which might have explained the keeping in place of the individual rods in the clusters. Living clusters suspended in the original fluid and enclosed in a hollow slide sealed with vaseline and a cover-slip, remained alive for several days, swimming about all the time, while in hanging drops they soon ceased moving, and were overgrown with colourless bacteria.

Attempts at cultivation started with material from one of the reddish patches sucked into a fine pipette and blown into soil-water tubes with various kinds of putrifying material, of which small pieces of cheese proved best. After 4 days, pink spots appeared in the test-tubes remote from the light of a north window. Next day, there was a rose-coloured little cloud just above the soil, and from there a whitish band stretched upwards. On the sixth day, plentiful colonies were seen forming whitish pink clouds which reached the surface, and soon after a reddish lilac aggregation formed in the uppermost portion of the fluid. After a week Chlamydomonas spp. appeared and reduced the reddish organism more and more. By repeatedly diluting and subculturing, the suspension of Vannielia aggregata could be maintained in cheese + soil tubes for several weeks, although not every culture was successful, owing to the admixture of green flagellates. Transfer of individual colonies with a capillary pipette into new putrifaction tubes was not successful. 
After several failures pure cultures were obtained by mixing drops of red motile Vannielia clusters into test-tubes with Difco nutrient agar, preferably diluted to one half with watery agar, and repeating this procedure several times. In the beginning, red and green colonies appeared after a week (north window, June 1953) in the more diluted suspensions, far enough from one another to be picked up after breaking the tubes and removing the agar columns. Heavily inoculated subcultures free of other bacteria showed maximum growth at about $5 \mathrm{~mm}$. from the agar surface, but small reddish colonies filled the agar down to the bottom.
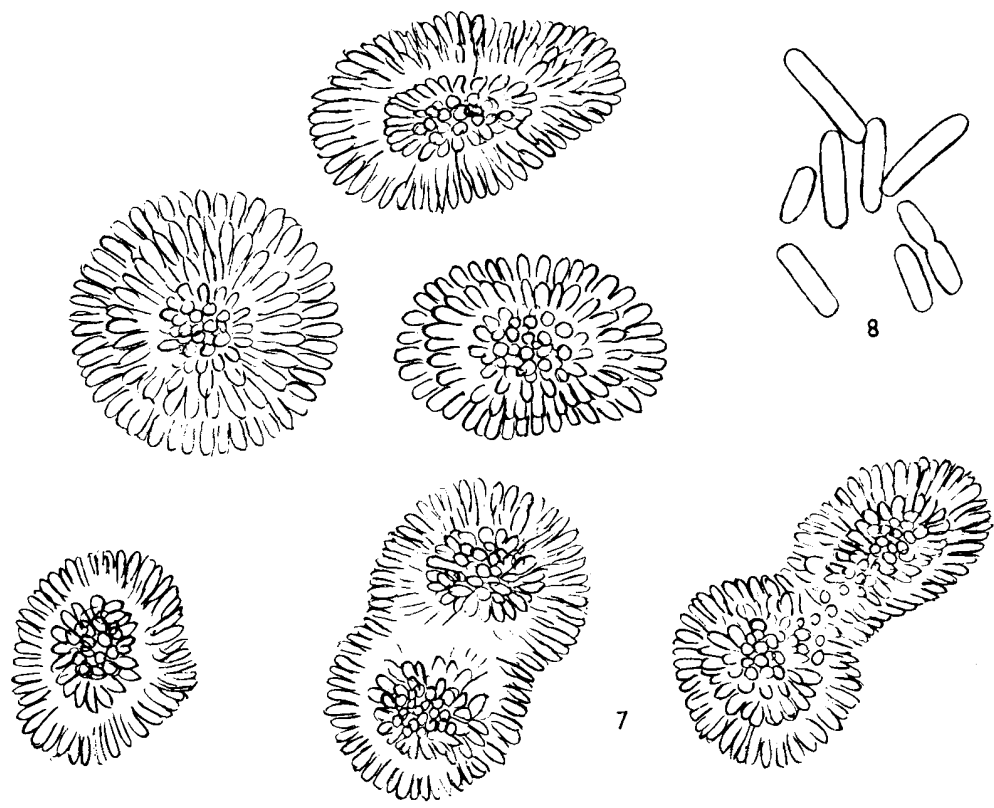

Figs. 7, 8. Vannielia aggregata.

Fig. 7. One colony normal and spherical, three irregular and longish, two in a state of division. The darker inner portion of the colonies only appears pinkish. $\times 1500$. Fig. 8. Individual cells. $\times 3000$.

The strain could be maintained in stab cultures, and growth occurred also in peptone yeast extract liquid media and soil + cheese + water cultures. No well-organized spherical clusters were, however, found in these, the nearest approach being small aggregations of cells only partly radially arranged. Single cells swimming with extraordinary rapidity were in the majority.

It is therefore not absolutely certain that the true Vannielia was isolated and, under unnatural conditions, aggregated in a more irregular way, though this seems to be the best explanation.

The genus Vannielia is obviously a member of the Athiorhodaceae and ought to be grown in conditions more similar to those at the habitat. This would be worth while, since formation of definite colonies is only known in the Thiorhodaceae (Thiopedia, Thiodictyon) but not in the sulphur-free purple bacteria. 
We speak of colonies of bacteria when small clusters of cells, often derived from one original cell, develop by binary fission into heaps of thousands or millions of cells and become visible to the naked eye. These are artificial colonies rarely found in nature. With other organisms, for instance flagellates and algae, but also with metazoa like Coelenterata and Bryozoa, and even with insects and mammals, the term colony is used in a different way, viz. for individuals living together under natural conditions and forming a community somehow biologically connected to be components of a whole. There are in bacteria not many instances of such communities.

Artificial colonies of bacteria growing in the habitual manner on semisolid media show of course very often a characteristic arrangement which is helpful in identification, for instance the curls of Bacillus anthracis, or the branched mycelium-like appearance of $B$. mycoides. But in liquid media this arrangement is lost, and nothing but chains of cells are observed. Only in very few species, as, for example, Zoogloea ramigera, Sphaerotilus natans and Crenothrix ochracea, the cells are kept together by mucilage or sheaths to constitute wellrecognizable structures. Others remain connected after cell division, without a special enveloping substance being recognizable, for instance Sarcina, Thiopedia, Thiodictyon spp. To this category belongs Lampropedia, remarkable for the great number of cells which may form such natural colonies, which are also produced on nutrient agar, so that artificial colonies are not much different from them.

Vannielia is of another type and more reminiscent of organized colonies as found in flagellates like Chrysophyceae (Synura), Craspedomonadaceae (Sphaeroeca) or Volvocaceae (Pandorina) in being composed of cells connected in the centre by their posterior ends and swimming with the help of flagella emerging from the individuals into the surrounding water.

In all these instances a unifying impulse must be supposed to correlate the action of the flagella; no regulated forward locomotion would otherwise be possible. Pelosphaera rotans (Lauterborn, 1915, p. 420, Pl. II, figs. 18, 19) with a diameter of the colonies of $15-40 \mu$. must be similar to Vannielia. According to Koppe (1923, p. 634), it occurred in smelly water of low oxygen content underneath a Lemna cover. This would be in keeping with the identity of Pelosphaera and Vannielia. But no colour is mentioned in the description, and the size is larger than that of Vannielia, so that identity is not probable.

The arrangement of the cells is different in Sarcina, Planosarcina (Migula, 1900) and Pedioplana (Wolff, 1907) species, but these colonies also are organized, swimming in a well regulated way with their flagella pointing in one direction, comparable to the colonies of Gonium among Volvocaceae.

\section{REFERENCES}

Ehrenberg, C. G. (1838). Die Infusionstierchen als vollkommene Organismen. Leipzig.

Kolkwitz, R. (1909). Schizomycetes, Spaltpilze (Bacteria). Kryptogamenflora der Mark Brandenburg, 5. Leipzig. 
Journal of General Microbiology, Vol. 13, No. 2


E. G. Pringsheim-Lampropedia and V annielia species. Piate 1

(Facing p. 291) 
Koppe, F. (1923). Die Schlammflora ostholsteinischer Seen und des Bodensees. Arch. Hydrobiol. 14, 634.

Kützıng, F. T. (1845-71). Tabulae phycologicae. Leipzig.

Lauterbonn, R. (1915). Die sapropelische Lebewelt. Ein Beitrag zur Biologie des Faulschlammes natürlicher Gewässer. Verh. naturh.-med. Ver. Heidelb. N.F. 13, 395.

Migula, W. (1897-1900). System der Bakterien, 2, 275. Jena: Gustav Fischer.

Pringsheim, E. G. \& Robinow, C. F. (1947). Observations on two very large bacteria, Caryophanon latum Peshkoff, and Lineola longa (nomen provisorium). J. gen. Microbiol. 1, 267.

Schroeter, F. (1886). 'Bakterien' in Cohn's Kryptogamenflora von Schlesien. 3, 151. WolfF, M. (1907). Pedioplana haeckeli. Zbl. Bakt. (2. Abt.), 18, 9.

\section{EXPLANATION OF PLATE}

Fig. 1. Colonies from agar, stained with fuchsin.

Fig. 2. A living, squarish colony.

Fig. 3. Older colony, uniform growth no longer maintained, with individual squares distinguishable.

Fig. 4. Large colony on agar; arrangement of cell-rows partly fan-like. Detachment from agar beginning along straight ridges conditioned by growth parallel to the surface of the medium.

Fig. 5. Outer portion of an older growth on agar, inner parts folded and to some degree lifted from the surface of the medium by growth pressure and friction.

Fig. 6. Colonies from surface of liquid medium, some of them curled and dark from adhering air. 